研究課題別研究評価

1. 研究課題名:

LTP 形成におけるミクログリアの役割の検討

2. 研究者名：

澤田＼cjkstart誠（藤田保健衛生大学総合医科学研究所）

3. 研究のねらい:

さきがけ研究では脳内での細胞間の協調による高次脳機能発現を調べるために LTP 形成に おけるミクログリアの役割を検討することを目的として行ない、

(1) 新生ラット大脳皮質スライス培養に単離ミクログリアを添加すると LTP 樣の EPSP の増大が 生じること

（2）ミクログリアの役割を動物個体レベルで検討するためのシステムとして脳特異的細胞移入 技術を確立したこと

（3）ドラッグデリバリシステム担体として有用な株化ミクログリアを創出し特許申請を行ったこと などの成果を得た。今回の研究によってミクログリアの脳機能発現における役割は多岐にわたり、 記憶や学習といった高次脳機能のメカニズムにまでおようシことがわかり、脳をシステムととらえ機 能発現の制御を理解する上て細胞間の協調という観点からとらえる必要があることを指摘できた。 また、細胞間の協調による脳機能発現の制御について個体レベルで検討するシステムを構築す ることができた。

乥こで、延長研究では、3年間の研究て構築することができたシステムの特性を生かしてミクログ リアによる細胞間の協調による脳機能発現の制御について分子生物学的、細胞生物学的に解 析するために以下のような研究を行う。

\title{
[ 研究の意義 ]
}

ミクログリアなどのグリア細胞か廭極的に脳の機能発現を調節しているという概念はこれまで ほとんど考えられてこなかった。さきが研究の3年間でミクログリアが少なくとも高次脳機能の 調節にかかわっていることか証明できた。このことを端緒にして、さらに脳内細胞の細胞間の協 調による脳機能発現の制御について研究を進めることにより、さきがけ研究で得られた成果をさ らに発展させることができると考えている。

[ 研究計画 ]

(1) ミクログリアの神経可塑性調節のメカニズムを調べる

ミクログリア導入の個体レベルでの効果

脳特異的細胞移入技術を用いて動物個体にミクログリアを導入し、賢いマウスが創出で きるかという観点から行動薬理的な解析をおこなってミクログリア移入の効果を調へた。実際 の行動解析にかかる実験システムは、痴呆モデル動物の行動解析を行っている名古屋大学 医学部鍋島教授との共同研究で行うよう計画を検討した。また、行動解析終了後、事業団貸 借物件の MED システムを用いて脳スライスを作成して電気生理学的に解析した。

（2）脳疾患の細胞治療への応用

脳特異的細胞移入技術およびドラッグデリバリシステム担体として有用な株化ミクログリア を用いることによって脳疾患に対する細胞治療の有用性を判定するシステムとして利用価値 がある。しかし実際に治療法として応用するにはマウスミクログリアを用いることは現実的で 
ない。乥こで、マウス株化ミクログリアを用いてこのシステムが実際の疾患に有用であるかを 検討すると同時に、脳特異的細胞移入を規定する分子を同定し、また、ヒト治療に利用でき る骨髄細胞中にミクログリアと同等の性質を持った細胞が存在するか否かを検討した。

1) 変性疾患モデル動物への遺伝子導入

脳虚血モデル、痴朵モデルなどにミクログリアを導入して炎の治療効果を検討した。

2) 脳特異的移入のメカニズム- - ホーミング分子の単離

ミクログリア細胞膜上に発現していると考えられる敛特異的ホーミングを起こすタンパク の遺伝子をクローニングした ミクログリア cDNA から構築したファージディスプレイライ ブラリーから目的分子を検索した。

3）骨骾細胞中の脳移行細胞の同定と光の性質の検討

マーカー遺伝子を発現している骨髄細胞を正常マウスに移植して脳に移行する細胞 を同定し、さらに分離培養して炎の性質を調べた。

4. 研究結果 :

1.はじめに - 脳疾患の治療の現状と難しさ (参考文献 1)

脳の疾患は非常に多く、従来補充療法により対処されている。しかし藏器の中で脳は血液脳 関門が存在するため、末梢からの物質や細胞の浸潤がほとんどなく、薬物や遺伝子導入か困難 である (図1)。実際に正常脳で T細胞やマクロファージなどの免疫細胞の浸潤はほとんどみら れない。脳の疾患を治療するためには有効な薬物や生理活性物質を脳入選択的に導入すること が必要であるが、脳に特異的な物質移送のシステムの開発には国内外の多くの研究者が取り 組んでいるにもかかわらず、非侵害的（直接脳に注入するような負担の大きい手術を伴う手技を 行わない)しかも脳特異的に導入するにはいたっていない。動物個体レベルでの脳内への遺伝 子導入については向神経性をもったヘルペスウイルスを用いた方法やアデノウイルスまたはア デノ随伴ウイルスを遺伝子のベクターとして用いる方法が考案され、神経細胞特異的に遺伝子 を導入できるシステムか報告されている。レトロウイルスベクターを用いる方法も作成され、肝蔵 や血液細胞などでは成功している。また、レンチウイルスベクターを用いることによってこれまで レトロウイルスベクターでは難しいとされていた神経細胞などの非分裂性の細胞にも効率よく遺 伝子導入でき、しかも高効率でタンパク質を発現させられることも報告されている。

しかし脳は血液脳関門が存在するため末梢からの投与では脳に特異的に導入することができ ず、したがって手術によって脳に直接注入する以外に方法がなった。一方、手術などの侵害的 な手技を伴わない方法としてリポソームを利用する方法があり、リポソームの構成要素を変える ことによって脳に比較的入りやすいものか国内のグループによって開発された。しかしこの方法 でも脳への取り込みは注入量の 1程度で、脳に特異的であるとはいえない。

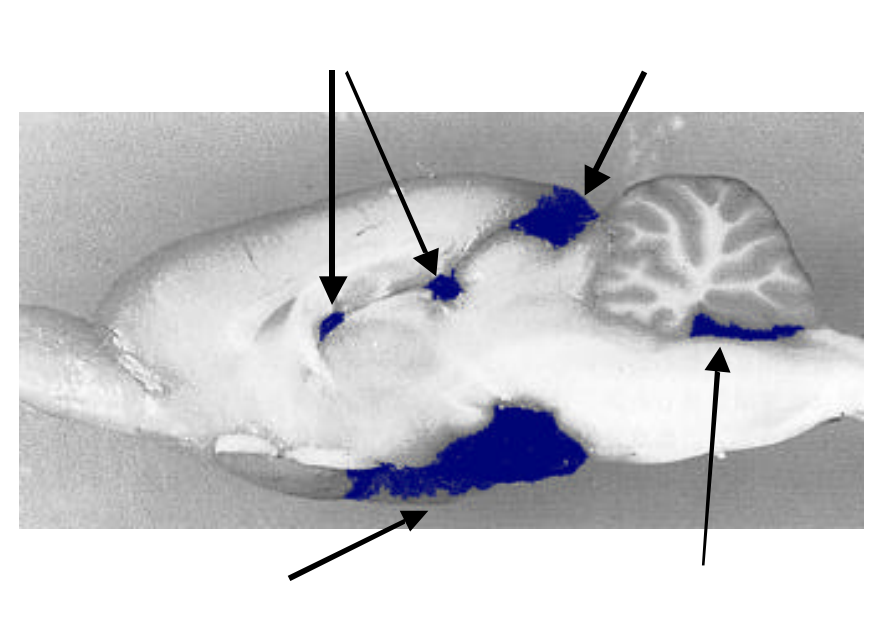


图1ラット血液中に青い色素を注入したときの脳への浸透

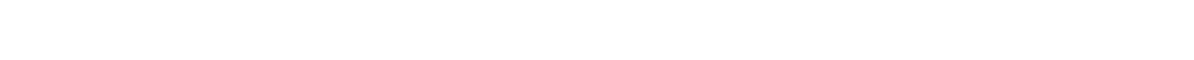

最近我々は新規な2つのことを発見し相次いて新聞記事として紹介された(参考文献 2,3)。光 の第一点は、脳に特異的な親和性をもつミクログリアの細胞株の樹立に成功し、これを末梢血管 投与することにより脳に特定遺伝子を限局して発現させるシステムを確立したことである。さらに ミクログリア細胞は高い貪食能を持つため、薬物や生理活性物質、タンパク質などをあらかじめ 取り込ませておけば、脳に特異的な物質輸送（ドラッグデリバリ）を実現する運搬担体となりうる。 一方、第二点は脳に導入したミクログリア谷のものが神経変性を抑制する働きを持つことで こ の点を応用することによってアルツハイマー病やパーキンソン病など治療法のない神経変性疾 患の新しい治療法を開発できる可能性がでてきたことについてである。この樣な細胞の特殊な性 質を利用して「脳特異的バイオターゲティング技術」を開発した。この技術の基本となる株化ミク ログリアについては科学技術振興事業団から国内および国際特許が出願済みで、現在公開され ている。

2. 脳のバイオターゲティング技術

2- 1 株化ミクログリア

ミクログリアは株化細胞を分離することか漢隹しく、これまでにがん遺伝子をもつたウイルスにより 形質転換して樹立した細胞とがん抑制遺伝子 p53 ノックアウトマウスから樹立した細胞力報告さ れているのみである。これらの細胞はマクロファージ樣性質力強く、脳に移植した場合神経細胞 やオリゴデンドロサイトに対する好ましくない影響か起こる可能性がある。またがん遺伝子や遺 伝子変異をもっているため、細胞の増殖の調節か灘しく、動物体内に注入したり移植したりした 場合に腫瘍を形成する危険性が高い。これに対し我々の樹立した株化ミクログリアは増殖因子 依存的に増殖し、因子非存在下では堌殖能を失い分岐したミクログリアの形態 (通常の脳内で見 られる形態) をとるため、生体内に移入しても腫瘍化する危険性はないと考えられる。もともと脳 内に存在する細胞の状態に戻るため、脳内に移植または移入してもほとんど悪影響は持たない と思われる。この樣な性質を持つ株化ミクログリアについては科学技術振興事業団から国内およ び国際特許が出願済みで、現在公開されている。

\section{2- 2 脳特異的な細胞の侵入}

われわれはミクログリアを貪食細胞に特異的に染色性を示す蛍光色素を用いて染色してラット の腋窩動脈に注入し光れら細胞の組織配向性を調べた。標識したミクログリアを注入した場合に は脳には多くの蛍光細胞が見られたが、肝臓にはわずかしか見られなかった。これに対しマクロ ファージを注入した場合には正常脳にはほとんど蛍光細胞が見られないが肝葴には多くの蛍光 細胞が見られた。以上の結果からミクログリアはマクロファージとは異なり脳に特異的な親和性 をもつた細胞であること、この親和性を利用すれば末梢血流中から特定物質や遺伝子を脳に特 異的に導入できることがわかった。

\section{2- 3 遺伝子運搬の坦体としてのミクログリア}

株化ミクログリアの一つに大腸菌由来の遺伝子である lacZ を発現するベクターを特定遺伝子 発現のモデルとして導入したものをラット血流中に注入して、脳に選択的に遺伝子を発現させる ことかできるかどうかを検討した。关の結果、lacZ 発現細胞を注入したラット脳切片で午の遺伝子 の転写産物である $\beta$ - galactosidase の活性が検出できた(参考文献 4)。この酵素活性は肝臓、腎 藏、脾藏、肺などの絾以外の藏器ではほとんど検出できなかった（図 2A)。すなわち、脳選択的 
に外来遺伝子を導入し、活性を持つ酵素を発現させることに成功したわけである。現在までは一 過性遺伝子発現導入(transient expression)法によって遺伝子を導入した株化ミクログリアを用い ているが、この方法でも導入後約 3 週間経過しても導入 2 日後の約半分から 3 分の1程度の酵素 活性の発現を示すことがかかった (図 2B)。また脳に導入した細胞は1ヶ月以上経過した段階で も導入直後の細胞数とあまり変わらないことから、いったん脳内に移入した細胞は排除されるこ となく光のまま脳内に生着すると考えられる。

(A)

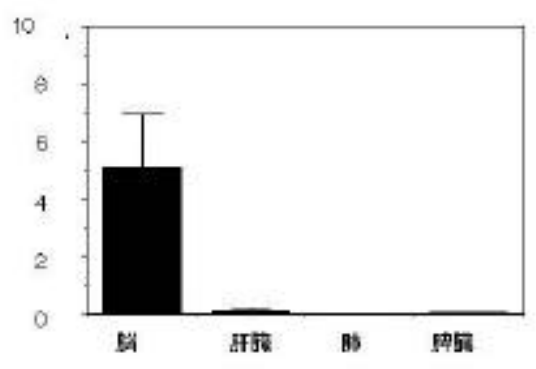

(B)

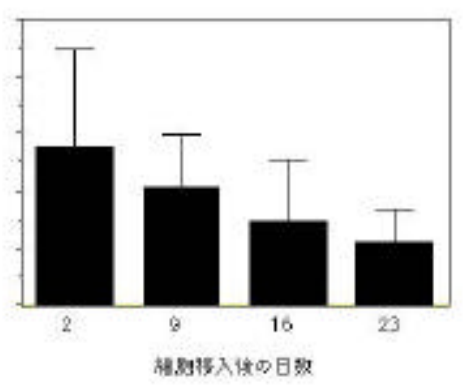

図 $2 \operatorname{lac} Z$ 遺伝子導入した株化ミクログリアを注入した動物での 藏器特異性。脳での活性は他の蔵器の 50-100 倍であった。

(B) 脳内での導入遺伝子発現の経時変化。導入遺伝子は約 3 週間後でも検出できた。

\section{2-4薬物を封入したマイクロカプセルの脳への運搬}

ミクログリアは脳に存在する貪食細胞であり、光の性質を利用するとある特定の化合物を大量 に取り込ませることかできる。たとえば、脳内に侵入したミクログリアの同定に用いている蛍光色 素は水溶液中で会合し貪食に適した大きさの顆粒状になる。この顆粒をミクログリアが貪食して 蛍光色素標識ができるが、同樣に脳に特異的に導入したい薬物についても疎水性官能基の非 対称的導入によるドラッグデザインの工夫によって顆粒状に凝集させるか、リポソームなどに封 入した物をミクログリアに貪食させれば、同樣に脳に特異的に導入できる。また、蛍光色素を封 入したラテックスビーズを取り込ませた細胞をマウス尾静脈に注入すると、脳内にミクログリア特 異抗原で標識される細胞の中にのみ蛍光を発するビーズが観察できた。 

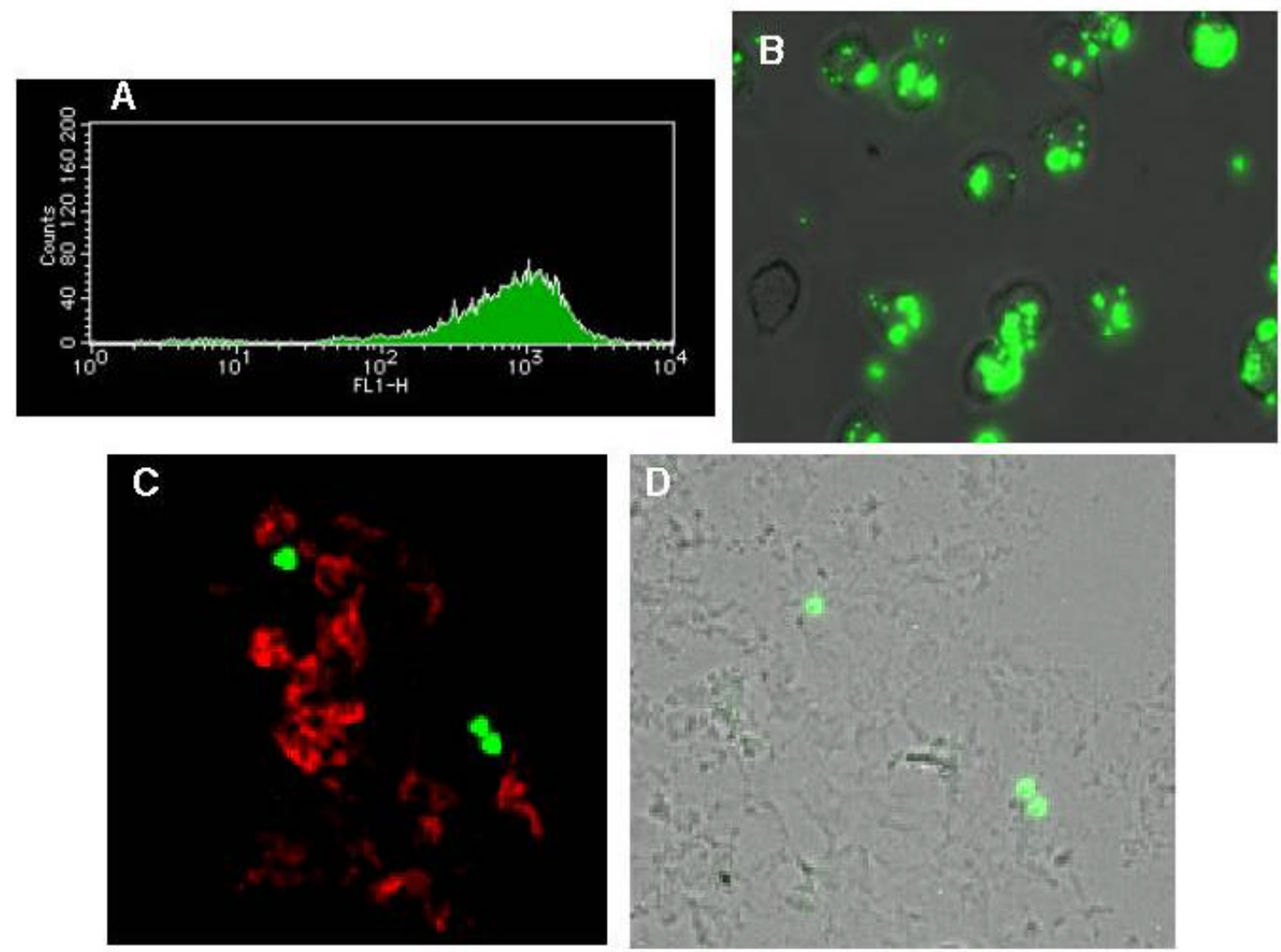

图 3 (A) 蛍光ビーズを取り込ませたミクログリアの蛍光強度の測定

(B) 蛍光ビーズを取り込ませたミクログリアの形態

(C) 脳内にミクログリアを認識する抗体で染色できる細胞に取り込ませた蛍光ビーズか観察で きた(D) C の位相差像

2- 5 脳に到達した細胞の MRIによる非侵襲的モニタリング

ミクログリアの貪食性を利用してマグネタイトなどの MRI 造影効果をもつ物質を取り込ませるこ とによって脳内に導入したミクログリアの動態を非侵襲的に観察できる可能性が考えられる。実 際に細胞治療を行う場合、導入した細胞の分布や動態力観察できることか望ましい。我々はラッ 卜を用いた実験により MRIを利用して脳内でマグネタイトを取り込んだ細胞が最低数千個の集団 として存在すれば観察できることを確認している。

\section{2- 6 脳に移行したミクログリアの脳に対する保護作用}

血管内注入することによって脳実質内に侵入したミクログリアは内在性ミクログリアのように分 岐した休止型になり長期にわたって脳実質内にとどまることがわかった。弚れでは外来性のミク ログリアは周囲の神経細胞や内在性のグリア細胞に対してどのような影響を持つのだろうか。一 般的に活性化したミクログリアは神経細胞やオリゴデンドロサイトなどに対して細胞障害性に作 用すると信じられているので、それらの細胞に対して変性を起こすような悪影響はないのだろう か。

ミクログリアがtoxicであるか trophicであるかについては直接脳内で調べるのが良いと思われ る。关こでミクログリアによる脳のバイオターゲティングを用いて一過性前脳虚血を起こした砂ネ ズミで遅延性神経細胞死が見られる海馬 CA 1 領域の錐体細胞層に標識ミクログリアを集積させ 
ることを行った。この時、内在するミクログリアも海馬の広範囲に渡って集積活性化し、一過性脳 虚血処理をしたが、遅延性細胞死が見られなかった例においても内在ミクログリアの集積活性化 か観察できた（参考文献 5) 。さらに、ミクログリアを脳内導入した場合や虚血再還流直後にミクロ グリアを注入した場合においては有意に $\underline{C A 1}$ 錐体細胞の神経細胞死が抑制されることがわかっ た。したがって、このシステムて調べる限りにおいてはミクログリアは海馬 CA1 錐体細胞の虚血 後にみられる遅延性神経細胞死に対して保護的であると考えられる（参考文献 6)。

このようなミクログリアの神経細胞死に対する保護作用が脳虚血後の遅延性細胞死以外の神 経变性や障害を受けていない健常な神経細胞に対してみられるかどうかは今後検討する必要が あるが、少なくともミクログリアを導入したマウス脳の長期観察からは神経変性などを生じせしめ ているような所見は得られておらず、導入したミクログリアは周囲の脳内細胞に対して悪影響を 及ぼすことはないように思える(参考文献 7$)$ 。

3. 脳のバイオターゲティング技術の展開と応用 ( 参考文献 8)

3- 1 脳のバイオターゲティング技術の展開

本技術を実際のヒト疾患への臨床応用を行うためにはヒトの脳に特異的に侵入できる細胞を分 離しなければならない。しかし、ヒトミクログリアを分離することは多くの制約がり難しく、さらに 遺伝子導入か可能な株化細胞を確立することはほとんど不可能と言える。さらにヒトに注入する 場合は自己非自己の問題も考えなければならない。したがって実際の技術利用においては以下 のような技術展開が必要となる。

（1）移行性分子および遺伝子の単離と光れに基づく薬物、遺伝子、細胞の脳への標的化：ミク口 グリアは脳という藏器を認識して光こに侵入する分子的な機構があり、これがラットやマウス、 ヒトといった種を越えてかなり共通のメカニズムで支配されている可能性があるという点に注 目し、細胞株の脳に侵入するために働くタンパク質を同定して产の遺伝子を分離し、ヒトの細 胞、たとえば骨髄細胞または臍帯血細胞に導入すればヒト細胞を脳に特異的に移入できる ことになる。また、機能分子をリポソームなどの人工坦体に埋め込むことによって細胞によら ないドラッグデリバリシステムを実現できると考えられる。さらに、これらの活性ペプチドを直 接標的化したい薬物に結合することによって薬物弚のものを脳に移行させることができる。

(図 4 われわれは現在、いくつかの方法論によりこの脳に侵入するために必要な基本分子 の単離について分離作業を行っている。

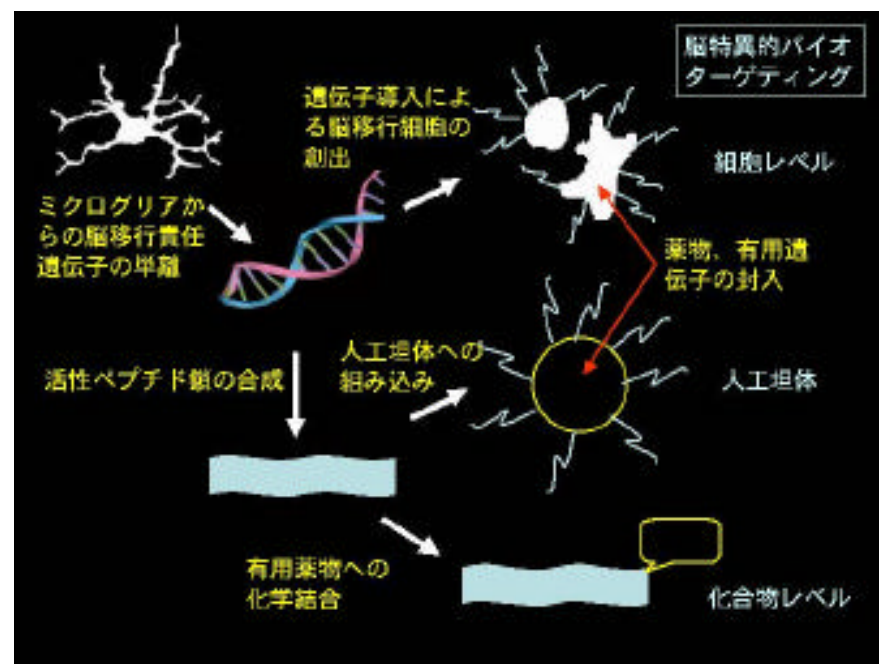

図 4 脳特異的侵入を規定する遺伝子およびシグナルペプチドの分離と脳のバイオターゲティング

（2）ヒト藏器をバイオターゲティングする場合に実際上用いる細胞として骨髄細胞の利用が考え 
られるが、骨髄移植による脳への細胞移行は報告がない。乥こでGFP 恒常的発現骨䯣細胞 を正常マウスに移植するシステムを用いて、骨骾細胞移植における脳親和性細胞の存在や その性質について検討した。炎の結果、レシピエントの脳と末梢㵴器において、移植骨髄細 胞由来の GFP 陽性細胞力䔟行していることか確認できた。このとき、末梢藏器でみられる GFP 陽性細胞数はホスト細胞のレシピエント骨髄への置換率に比例して増大していたが、脳 内でのGFP 陽性細胞数はこの置換率には無関係であった。さらに脳と末梢臓器でのGFP陽 性細胞では細胞表面の分化抗原の発現が異なり、脳における GFP 陽性細胞は、末梢蔵器 に比較して未分化であり通常の単球では発現しえない抗原を発現していることを見いだした。 この結果から脳に移行した細胞は末梢蔵器に移行した細胞とは異なり、骨髄で単球に分化 してから藏器に侵入したのではなく、移植時に血流中に投与された未分化な造血系前駆細 胞の一部か直接脳に侵入したと考えられる。したがって、骨髄中の造血系前駆細胞中にはミ クログリアのように脳に親和性を持って侵入できる細胞が存在し、この細胞を単離培養でき れば脳特異的バイオターゲティング細胞として用いることか可能となる。さらに自己の骨䯣細 胞または臍帯血細胞の培養細胞を用いれば自己非自己の問題も克服できる。土分にヒ卜疾 患の治療に対して応用できる可能性があると考えている。しかし、骨骨道に存在する脳に親和 性を持った細胞はごく少数しか存在せず、今後この細胞の効率のよい分離法や、特異的な 増殖条件等を検討する必要があると考えられる。
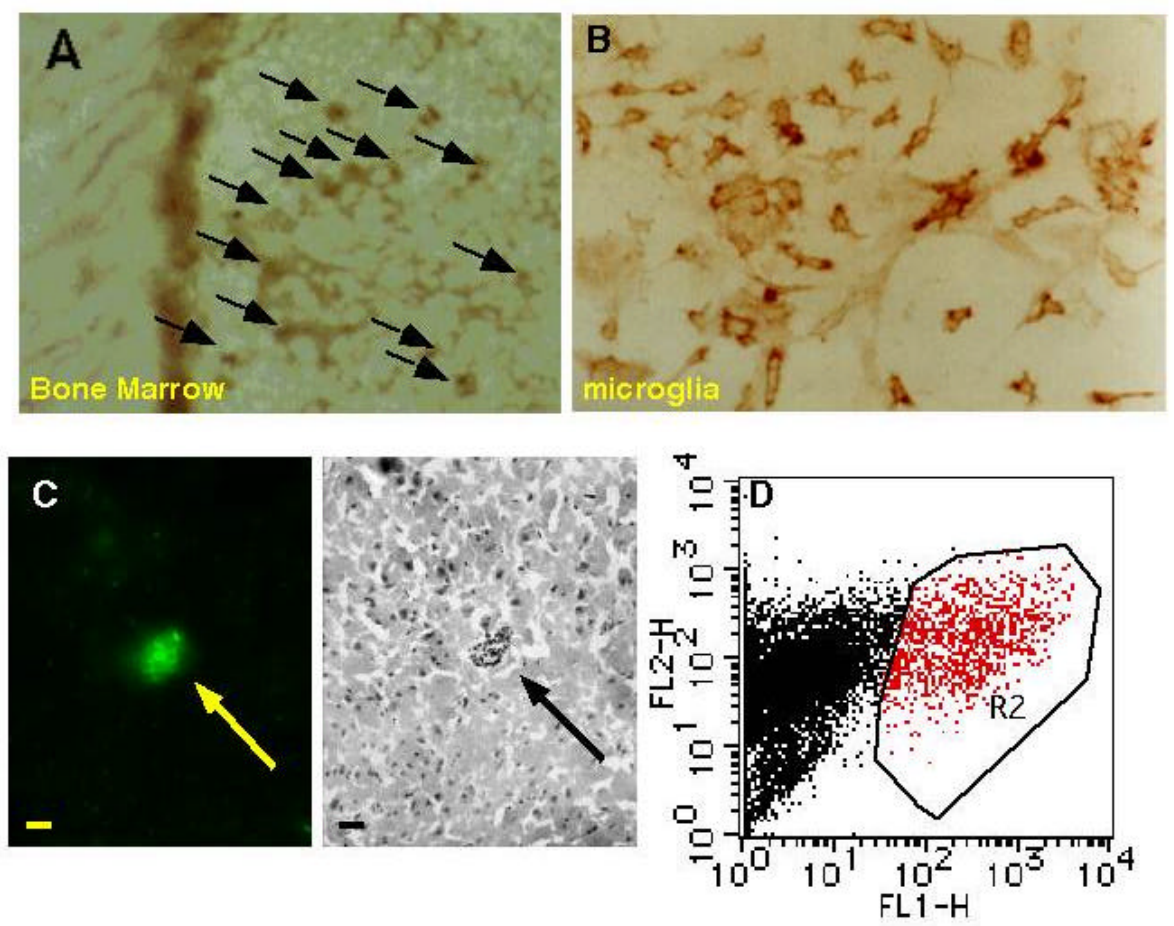

図 $5(A, B)$ 骨髄未分化細胞 $(A)$ とミクログリア(B)に共通に発現している分子

(C) 骨髄移植によって脳内に侵入した骨髄細胞 (D) 脳に移行する能力がある骨髄細胞の精製

\section{3- 2 脳のバイオターゲティング技術のヒト疾患への応用}

我々カ開発した株化ミクログリアを用いた脳をターゲッティングしたドラッグデリバリシステムは 細胞を用いたいわゆる cell therapy であるため、薬物などの化合物だけでなくあらかじめ目的遺 伝子を細胞に導入しておくことて酵素やタンパク質を脳内て持続的に発現させることができる。し たがってあらゆる脳神経疾患の治療に応用することができると考えている。また、血管に注入す るだけで脳に特異的に移入されるので、重篤な手術を行うことなく目的を達成できる。マウスやラ 
ットでは尾静脈に注入した細胞も脳に移入できることから、ヒトの場合、静脈の点滴などでも導入 できると考えられる。

脳神経疾患の治療に対しての治療戦略としては、以下の5つの場合に応用することが可能であ る。

（1） 欠損または変異などによって量や活性が低下した酵素や生理活性タンパク質を補う補充療 法 : これは遺伝子欠損や遺伝子変異により特定の酵素またはタンパク質が脳内で欠乏する ことによって生じる樣々な脳疾患に対し、欠乏するタンパク質や酵素の遺伝子を導入した細 胞を注入することにより行われる。また、特定の神経細胞か変性脱落するパーキンソン病や アルツハイマー病に対し、神経の変性脱落により欠乏する神経伝達物質の合成を促進する ような遺伝子、たとえばパーキンソン病におけるチロシン水酸化酵素やビオプテリン合成酵 素などのドーパミン生合成系の酵素遺伝子が考えられる。

(2) 変性などで脱落する神経細胞を保護し機能を強化する保護療法 : 変性疾患や脳虚血など 色々な原因で生じる神経細胞死を抑制し、神経突起の再生を促す神経栄養因子(NGF, BDNF, GDNF, NT3など。特にパーキンソン病では BDNFや GNNF か洧効であることが近年 示されている。）遺伝子を発現する細胞を注入することが考えられる。また多発性硬化症の ように免疫細胞か関与する疾患では免疫抑制作用がある TGF $\beta$ や IL- 10遺伝子を発現する 細胞を導入することが考えられる。

（3）腫瘍や血栓などを除去するような方法 : 抗腫瘍作用を持つ因子を発現させたり抗がん斉を導 入した細胞を脳に移入したりすることが考えられる。血栓除去については線溶系の酵素を発 現させることが考えられる。

（4）有効な薬物を脳にだけ導入するような方法 : 神経系に作用を持つ薬物は末梢毒性が高かつ たり、末梢神経系に作用を持つ物、血液脳関門を通過しにくい物など色々あり、脳への特異 的なドラッグデリバリーシステムが必要とされていた。今回のシステムでは末梢藏器にあまり 影響を与えず脳に特異的に薬物投与ができると考えている。

(5) 脳疾患予防システムとしての利用法: もともとミクログリアは光の細胞の性質として変性や炎 症部位に集まり死細胞を取り除き損傷修復にも関わったり、抗腫瘍作用や抗ウイルス作用 を持つ、いわば脳内防御システムともいうべき細胞であることから $(11,19,20$ ) 弚の性質 を遺伝子操作などて強化することによって単一疾患の治療だけでなく、脳内防御システム光 のものの強化を行うことによってあらゆる疾患に対する予防措置にも応用しうる。

4. 脳のバイオターゲティング技術の問題点

41 脳の特定部分のターゲティング

担体となる細胞は理想的には脳の病変部位にだけ移入させることか望ましいが、末梢血管か らの細胞投与では脳全体に広がって細胞か移入する。关こで脳動脈力テーテルを用いてミクログ リアを目的とする病変部位近傍の局所脳循環に投与したり、細胞に導入する遺伝子の発現を遺 伝子工学的手法によって病変部に限局して発現させることによっても部位特異性をもたせられる と考えている。後者の場合、活性化したミクログリアで発現するTNFa や iNOSのプロモータを用 いることによって、病変部近傍に侵入して活性化したミクログリアに特異的に目的遺伝子を発現 させることかできると考えられる。もしくは電磁波やレーザーを使った温熱療法と組み合わせて熱 ショックタンパク遺伝子プロモータで目的遺伝子を発現させられるようにしたミクログリアを導入す ることなども考えられる。光のほかいろいろな可能性がある。また前述したように、ミクログリアは 変性や炎症部位に集まる性質を持つため、単にミクログリアの性質だけを利用するだけでも有効 な゙治療に結びつく可能性もある。実際に前述した一過性脳虚血後の遅延性細胞死に対しては海 馬錐体細胞層に外来性ミクログリアが虚血によりダメージを受けることで多く侵入し、神経細胞死 を抑制することが観察された。 
このような方法を単独または組み合わせて行うことによって多くの脳神経疾患の治療か可能と なると考えられる。現在まだ動物実験の段階ではあるが、脳腫瘍、脳虚血、パーキンソン病やア ルツハイマー病などの変性疾患、多発性硬化症、遺伝疾患であるリソゾーム蓄積症などのモデ ル動物に対して有効性をいくつかの医療機関との共同研究で検討している。

42 細胞移植上の問題点

実際のヒト疾患への応用にはいくつかの克服しなければならない問題点がある。最大の問題 はヒトの脳に特異的に侵入できる細胞を分離しなければならないことである。さらにヒトに注入す る場合は自己非自己の問題も考えなければならない。現在開発中の技術展開によりこれらの問 題は解決できると思われる。

\section{5. おわりに}

近年の発生工学的手法の進歩によりジーンターゲッティング法か確立され染色体遺伝子への 欠失の導入や変異遺伝子の正常遺伝子による置換が可能になり、遺伝病などに対する遺伝子 治療の可能性が一歩前進した。しかしヒトを対象とする発生工学的手法の導入には倫理的問題 等の難問があり、現在のところ特定の藏器に限った遺伝子導入か現実的である。

脳への選択的物質移送のシステムの開発には国内外の多くの研究者か取り組んでいるが、有 効性や安全性から実際に治療に用いることは難しい。しかし今回筆者らか開発した株化ミクログ リアを用いる方法は正常で脳に存在する細胞を担体に用いること、この細胞は脳以外の藏器に あまり親和性をもたないこと、継代培養ができるため遺伝子導入したクローンが分離できること、 血管内注入により脳にターゲッティングできることなどの多くの利点をもち、これまでにない有用 な方法であると考えられる。現時点ではなせ細胞が脳にはいるのか、脳に対する特異性はなに によって規定されているかなどわかっていないことか多くあるが、これらの疑問点の解明とともに、 今後ヒト疾患の治療に応用されるべく研究が進展していくものと期待している。

\section{参考文献}

1. 澤田誠 : ミクログリア細胞株を用いた脳疾患の治療の可能性. 日本醫事新報, 3844:28-30、 1997.

2. 中日新聞 1996.11 .1 第1面、手術なし脳治療に道、世界初の手法開発- - 抗がん斉や遺伝子 細胞が患部に運搬

3. 中日新聞 1999.10 .20 第 3 面、脳細胞死滅を防ぐ作用 - 藤田保健大グループミクログリア 研究「アルツハイマー」治療に道

4. Sawada, M., Imai, F., Suzuki, H., Hayakawa, M., Kanno, T., Nagatsu, T.: Brain- specific gene expression by immortalized microglial cell- mediated gene transfer in the mammalian brain. FEBS Lett., 433:37- 40, 1998.

5. Imai, F., Sawada, M., Suzuki, H., Zlokovic, B.V., Koijima, J., Kuno, S., Nagatsu, T., Nitatori, T., Uchiyama, Y., Kanno, T. : Exogenous microglia enter the brain and migrate into ischaemic hippocampual lesions. Neurosci. Lett. 272, 127- 130, 1999.

6. Sawada, M., Imai, F., Suzuki, H., Kanno, T.: Brain specific migration and protective roles in ischemic brain lesion of microglia. Rev. Neurol. IV th Eur Meeting of Glial Cell Function in Health and Disease. 78, 2000.

7. 澤田誠 : ミクログリアの新規な性質と脳での役割一ミクログリアは脳でなにをしているか。細胞 工学 18: 550-558,1999.

8. 澤田誠 : ミクログリア細胞を用いた脳疾患の治療戦略。神経進歩 45: 63 72, 2001. 
5. 自己評価

今回の延長研究においては、前のさきがけ研究において研究させていただいた時に光の可能 性について考察したミクログリアの新たな有用な性質について、弚の可能性の一部を証明できた ことが大いに有意義であったと考えています。前研究では神経伝達に特化したミクログリアの性 質を調べること、また产の研究のための新しい技術を開発することを目的に行いましたが、今回 はもつと広範囲な応用について研究することができました。乥の結果、ミクログリアを用いた脳の バイオターゲティングシステムを構築することができ、さらに、乥の応用としてヒトの細胞治療に応 用するための脳移行性責任遺伝子の候補遺伝子断片をクローニングできたこと、また、骨骨道細 胞中にもミクログリアと同樣な脳移行性を持った細胞か存在することか証明できたことなど、研究 の幅を広げることができました。実用化という点でも今回の延長研究の成果をさらに追求すること によりいくつかの遺伝子や方法論など研究の中から実用化できる対象をはっきりと絞ることがで き、有意義であったと思います。これらを権利化することによって更に実用化を目指した研究に発 展できると考えています。

さきがけ研究では文部科学省の科学研究費などのほ力の研究費とことなり、自由度か高いこと、 物品購入や会計などのサポートの業務を領域事務所が負担してくださること、弚のほか領域会 議やシンポジウムて情報交換ができることなど、個人研究を行う上での最良の条件を設定してい ただけるよいシステムだと思います。このシステムのサポートによって今回のような成果か出せ たことは大変うれしく思いますと同時に、すべての面に関わってくださった領域事務所のみなさま、 JST 個人研究推進室のみなさま、評価委員の諸先生方に心より感謝いたします。

\section{6. 領域総括の見解 :}

澤田研究者は、平成 8 から1 1年にかけて「知と構成」領域で研究を通して、高次脳機能発 現に関わる神経可塑性においてミクログリアが大きな役割を担っている可能性を指摘した。また、 ドラッグデリバリシステム担体として有用な株化ミクログリアを創出した。延長期間においては

（1）ミクログリアによる神経可塑生調節のメカニズムの解明と ( 2 ) 株化ミクログリアの脳疾患治療 への応用を目標として研究に取り組んだ。（1）についは、必ずしも、十分の進捗がみられたと はいい難いが、（2）については、2年間の延長によって、大きな成果力得られている。脳に特異 的な親和性をもつミクログリアの細胞株の樹立に成功し、これを末梢血管投与することにより、脳 に特定遺伝子を限局して発現させるシステムを確立した。また、脳に導入したミクログリア光のも のか神経変性を抑制する働きを持つことを明らかにした。これらの成果は、脳腫瘍、脳虚血、パ 一キンソン病、アルツハイマー病など脳疾患の治療に大きな道を開いたものとして高く評価され る。澤田研究者は、株化ミクログリアの特殊な性質を利用しての特異的な物質輸送を「脳特異的 バイオターゲティンク技術」と呼んでいるが、これはわか国から発信した新しい技術であり、今後 の展開を期待したい。

7 . 主な論文等 :

【学術論文】

(1) Suzuki, H., Imai, F., Kanno, T., Sawada, M.: Preservation of neurotrophin expression in microglia that migrate into the gerbil's brain across the blood brain barrier. Neurosci. Lett. 312: 95- 98, 2001.

(2) Iwata, A., Miura, S., Kanazawa, I., Sawada, M., Nukina, N.: a- Synuclein forms a complex with transcription factor Elk-1. J. Neurochem. 77; 239- 252, 2001.

(3) Katoh, Y., Niimi, M., Yamamono, Y., Kawamura, T., Morimoto- Ishizuka, T., Sawada, M., Takemori, H., Yamatodani, A.: Histamine production by cultured microglial cells of the mouse. Neurosci. Lett. 305; 181- 184, 2001. 
(4) Ishiguro, H., Yamada, K., Sawada, H., Nishii, K., Ichino, N., Sawada, M., et al (other 7 persons): Age- dependent and tissue specific CAG repeat instability occurs in mouse knock- in for a mutant Huntington's disease gene. J. Neurosci. Res. 65; 289- 297, 2001.

(5) Imamura, K., Sawada, M., Ozaki, N., Naito, H., Iwata, N., Ishihara, R., Takeuchi, T., Shibayama, $\mathrm{H}$.: Activation mechanism of brain microglia in patients with diffuse neurofibrillary tangles with calcification: a comparison with Alzheimer disease. Alzheimer Dis. Assoc. Disord. 15; 45- 50, 2001.

(6) Morihata,H., Kawawaki, J, Sakai, H, Sawada, M., Tsutada, T., Kuno, M.:Temporal fluctuations of voltage-gated proton currents in rat spinal microglia via $\mathrm{pH}$-dependent and -independent mechanisms, Neurosci. Res. 38; 265- 271, 2000.

(7) Kanzawa, T., Sawada, M., Kato, K., Yamamoto, K., Mori, H., Tanaka, R.: Distinctive regulation of antigen presentation by different type of murine microglial clones. J . Neurosci. Res. 62; 383 388, 2000.

(8) Hasegawa, Y., Sawada, M., Ozaki, N., Inagaki, T., Suzumura, A. : Increased soluble tumor necrosis factor receptor levels in the serum of elderly people. Gelontology, 46; 185-188, 2000.

(9) Hasegawa, Y., Inagaki, T., Sawada, M., Suzumura, A. : Impaired cytokine production by peripheral blood mononuclear cells and monocytes/macrophages in Parkinson's disease. Acta Neurol. Scand. 101; 159-164, 2000.

(10)澤田誠：ミクログリア細胞を用いた脳疾患の治療戦略＼cjkstart神経研究の進歩 45:63-72,2001

\section{【学会発表】}

[国内学会・会議・シンポジウム・特別講演]

(1) Sawada, M., Imai, F., Suzuki, H. (2001) Brain- Specific Migration and Protective Roles in Brain Damage of Microglia; A New Therapeutic Approach for Catecholamine Neuronal Dysfunctions. 9th International Catecholamine Symposium. Kyoto, March 31- April 5.

(2) Sawada, M. (2001) Neurotoxic vs Neurotrophic Effects of Microglia. 8 th MPO Meeting, Yokohama, Oct 1415.

(3) Imai, F., Sawada, M., Suzuki, H., Ninomiya, T., Kanno, T. (2000) Development of Brain-Targeted Cell Therapy Using Microglia as a Vehicle. 12th World Congress of Neurosurgery, Sydney, September 16-20.

(4) Sawada, M., Imai, F., Suzuki, H., Kanno, T. (2000) Brain- Specific Migration and Protective Roles in Ischemic Brain Lesion of Microglia. IV European Meeting on Glial Cell Function in Health and Disease. Barcelona, May 24 27.

(5) Sawada, M. (2000) Identification of novel characteristics and possible origin of microglia. Int MPO Meeting, Atami, J une 25- 26.

(6) 澤田誠 (2001) ミクログリアによる脳特異的遺伝子導入 (特別篝演) 第5回活性アミンシンポ ジウム、東京 8 月 24 日

(7) 澤田誠 (2001) 脳疾患における脳内免疫反応 : ミクログリア活性化の意味 (シンポジウム) 第 2 回日本分子脳神経外科学会、名古屋、9月 78 日

(8) 澤田誠 (2001) 脳特異性バイオターゲッティンク技術 (シンポジウム) 第3回 国際新技術フ エア2001、東京、1 1 月 1315 日

（9）小野健治、田中謙二、瀧井猛将、小野崎菊夫、澤田誠（2001）骨骨道由来脳移行細胞の性質、 第 74 回日本生化学会大会、京都 October 25-28.

(10)鈴木弘美、今井文博、神野哲夫、澤田誠（2001）脳虚血におけるミクログリアの神経細胞に 
対する保護作用、第 74 回日本生化学会大会、京都 October 25- 28.

(11) 小野健治、田中謙二、瀧井猛将、小野崎菊夫、澤田誠 ( 2001 第 24 回日本神経科学 ·第 44 回日本神経化学 合同大会 (Neuro2001) 京都, Sep, 26-28

(12)田中謙二; 鹿島晴雄; 川上真紀子; 澤田誠 (2001) ミクログリアはモノアミントランスポータ 一とカテコラミン代謝能を持つ第 24 回日本神経科学・第 44 回日本神経化学 合同大会 (Neuro2001) 京都, Sep, 26-28

(13) 小野健治、田中謙二、瀧井猛将、小野崎菊夫、澤田誠 (2001) 骨䯣由来脳移行細胞の性質、 第 27 回東海遺伝子医療研究会、名古屋、2月 9 日

(14)鈴木弘美、今井文博、神野哲夫、澤田誠（2001 脳虚血におけるミクログリアの神経細胞に 対する保護作用、第 27 回東海遺伝子医療研究会、名古屋、2 月 9 日

(15) 澤田誠 (2000 ミクログリアの新規な性質と細胞起源 (シンポジウム) 第 43 回日本神経化学 会、金沢、Oct 18 - 20.

(16)澤田誠 (2009 細胞を使って脳の疾患を治療する (特別講演) Cell Biology Meeting 2000,修 善寺 July, 1- 2 .

(17) 小野健治、瀧井猛将、小野崎菊夫、澤田誠（2000 骨髄キメラマウスでの脳移行性細胞の解 析、第 73 回日本生化学会大会、横浜 October 11- 14.

(18)鈴木弘美、今井文博、神野哲夫、澤田誠（2000 脳虚血におけるミクログリアの神経細胞に 対する保護作用、第 73 回日本生化学会大会、横浜 October 11- 14.

(19) 山田晃司, 澤田 誠, 他 10名(2000)ハンチントン病モデルマウスを用いた CAGリピートの不 安定性に関する研究、」第 73 回日本生化学会大会、横浜 October 11- 14.

(20)鈴木弘美、今井文博、神野哲夫、澤田誠（2000 脳虚血におけるミクログリアの神経細胞に 対する保護作用、第 43 回日本神経化学会、金沢、Oct 18-20.

(21)田中謙二, 澤田 誠, 鹿島晴雄(2000)ミクログリアのカテコラミン受容体、第 43 回日本神経 化学会、金沢、Oct 18-20.

(22) 澤田浩秀, 澤田誠, 他 10 名(2000) ハンチントン病モデルマウスを用いた神経病理組織学 的検討,第 23 回 日本神経科学大会, 第 10 回 日本神経回路学会 合同大会

(23) 澤田浩秀, 澤田 誠, 他6名 (2000)モデルマウスを用いたハンチントン病の発症機構解明 に関する研究、第 64 回 生化学会 中部支部会、名古屋、5月 13 日

\section{取材報告}

（1）時事通信社産業部 湯川 鶴章 (平成13年11月 14日) ミクログリアの脳特異的侵入と神経 疾患への治療への応用の可能性、特許の詳細、実用化の時期、方法など

\section{【報道】}

・ 中日新聞 2001.11.16 第3 面、脳に薬斉運、滀胞増殖法の開発成功 - 藤田保健衛生大 の澤田教授

・ 神戶新聞 2001.11.16 第3面、脳に薬はこij畄胞増殖 愛知の大学教授か潤発、幹部 に直接作用

・ 北海道新聞 2001.11.16 ミクログリア、運びや細胞増殖に成功 - まるでミクロの決死巻、 血管通り薬剂を直接脳疾患部入

・長野日報 2001.11.16 脳疾患治療に道開く、薬はこミぶバイオ技術開発 — 藤田保健大澤 田教授、国際特許を申請

・ 日本工業新聞 2001.11.19 脳に薬を効率運搬、藤田保健衛生大がバイオ技術、痴呆治療 などに道開く

・インターネットニュース 2 件 
・ Yahoo! Japan ホットニューズ 2001.11.16

・時事通信 HP ニュース速報 2001.11.16

・選択出版 山本、フリーライター 森山和道(平成 13 年 12 月 5 日)研究室見学、写真撮影、 研究者としての背景、これまでの研究の概要、現在の研究内容 (ミクログリアの脳特異的侵 入と神経疾患への治療への応用の可能性、特許の詳細、実用化の時期、方法など）杂倠誌 「選択」平成 14 年 2 月号 Sci\&Tech Frontier エウレカ 2112 回「脳の掃除屋は芸達者」 